a host for the viruses to which it is sensitive". In the introduction, N. W. Pirie had stressed the lack of evidence that viruses penetrate the bacterial cell wall ; their multiplication on, rather than within, the wall would be compatible with Anderson's evidence. As often happens when viruses are under consideration, the discussion took on a slightly metaphysical tinge. Felix urged a return to Bordet's view that bacterial viruses are fragments of the bacterial cell; but Anderson, because of the absence of serological relationships between the viruses and host cell constituents, saw no advantage in this hypothesis. A lysin can be made by ultra-violet irradiation of some viruses; A. Pirie asked if this should be looked on as an enzyme attacking a substrate in the cell surface or as an activator for the autolytic mechanism already present in the surface. Anderson said he did not know how often a molecule had to do the same job, without being destroyed, before it should be called an enzyme. There is no evidence that the substances postulated in these processes act more than once.

The part of the bacterium that is responsible for its mechanical integrity was only discussed briefly. I. M. Dawson showed electron-micrograms of the rigid cell wall made by centrifugal fractionation of a suspension of staphylococci that had been shaken with glass beads, and $J$. Smiles described the elastic properties of the membrane surrounding various organisms and of the septa which form before or during cell division. In different organisms these structures have characteristically different properties when subjected to stresses by flow of the medium or by drying. The general properties of these mem. branes were surveyed by E. T. C. Spooner from the point of view of the bacteriologist, but nothing was said about their chemical nature.

The last paper to be discussed was by A. Pijper, on bacterial motility, and this subject was also the main theme of A. A. Niiles's introduction from the chair. Pijper contends that bacteria move by virtue of an undulatory or corkscrew movement of their bodies, and that the flagella are wisps of slime trailing in the medium. He does not deny the existence of flagella, but looks on them as the consequence rather than the cause of motility. Observations on living bacteria under dark-ground illumination with sunlight give the main evidence for this point of view, and some of the phenomena were illustrated by a cinematograph film. Here it appeared that the direction of movement of the body is the first thing to change, and that it is only after this has happened that the flagella move round to the rear of the moving organism. Pijper's view was hotly contested. T. Y. Kingma Boltjes thought the mechanics very improbable and preferred the conventional interpretation of motility. A. Fleming confessed himself nearly convinced, but found his own observations on the rotational movements of Proteus grown in the presence of penicillin more nearly compatible with the concept of active flagella. This movement only takes place when the specimen is illuminated, and it appears that, when the light is turned on, flagellar movement precedes movement of the organism. The uniformity of flagella in electron-micrograms, and especially the fact that in one organism (unclassified) two distinct sizes are seen, together with the constancy with which the same number of flagella are seen in the same place on the members of one species, seemed to A. L. Houwink to rule out the trailing slime hypothesis. A similar attitude was taken by
W. van Iterson, who showed electron-micrograms of flagella apparently connected with the protoplast or with granules. Their formation from these structures would suggest that they are not formed by the casual streaming away of surface slime but are a specific extrusion. What is known of the chemistry of flagella makes such an origin probable. Conclusions about their origin do not, however, radically affect the problem of flagellar movement and, although Pijper's interpretation contains undoubted difficulties, no clear refutation of it was forthcoming.

It was generally agreed that this symposium was valuable, and that much of its value depended on the 'preprinting' of the main contributions. This technique is already used regularly by some societies; but its expense is bound to keep it from being adopted widely. It may therefore be legitimate to argue briefly the national economics of such meetings. Three hundred people attended this one, and at least two hundred of them were paid directly or indirectly out of public funds. The average of their salaries is certainly not less than $£ 2$ per working day. For an all-day meeting some are away for more than a day and many get travelling expenses. The hidden cost to the community of such a meeting is $£ 500$ at the lowest estimate, quite apart from the ordinary cost to the society. This expense is fully justified; but it is important to recognize that it is there, and to ensure that the best use is made of the time and money spent. If, by 'preprinting' the papers, we can increase significantly the value to the participants of the time spent in a meeting, it seems not unreasonable that the cost of 'preprinting', $£ 100-£ 200$, should be borne by public funds.

N. W. PIrIE

\section{NATURAL PRODUCTS IN THE BRITISH COLONIAL EMPIRE}

THE second peport of the Colonial Primary Products Sommittee*, dated January 1949, consistamoily of a series of commodity studies, to which is ppended a note by the Imperial Institute on diftillation of essential oils, describing inexpensive p a.t "for this purpose. Recommendations of the Cdd mittee in regard to groundnuts are discussed elsewhere (p. 889 of this issue); in regard to oil-palm products, the Committee recommends the introduction of a superior grade to encourage the production and sale for export of an oil suitable both for edible and technical purposes. The Committee considers that for coconut products a long-term assurance is of the first importance; but of other edible oils and oil-seeds yielding edible oils produced in the Colonial Empire, kapok seed, neem oil and dika fat are unlikely to be of use for edible purposes, special encouragement of sesame is not recommended, and of the minor oil-seeds only cottonseed and illipe nuts appear worth encouraging. The best hope of increased production of soya beans in the near future appears to lie in East and Central Africa, and the Committee hopes that the assured market will stimulate increased production there, and that departments of agriculture will pursue their variety trials. It suggests that if the large-scale trials of sunflowers as a rotation crop in Tanganyika prove satisfactory, consideration should

* Colonial Office. Colonial Primary Products Committee. Second Report, January 1949. (Colonial No. 238.) Pp. C0. (London: H.M. Stationery Office, 1949.) 18 . net. 
be given to growing the crop extensively elsewhere. It also considers that every effort should be made to increase Colonial production of drying oils to reduce the gap between sterling demand and sterling supply, and hopes that the present acreage of linseed in Kenya will be maintained, if not extended. Attention is also directed to the considerable possibilities of the candlenut tree, Aleurites moluccana, as a native-grown permanent tree crop, and to the desirability of establishing trial plantings over a wide range of conditions. It is suggested that the Colonial Products Research Council should undertake decortication trials with samples of nuts with the view of evolving a suitable decorticator for Colonial conditions. Production in the Empire of tung oil is centred in Nyasaland, and if the yield from the Colonial Development Corpora. tion's project in the Vipya Highlands materializes, together with production in the Southern Province in eight or ten years, much of the United Kingdom's demand should be met. Trials with the cultivation of high-yielding strains of castor giving non-scattering seeds are recommended, and also further trials of rubberseed oil and the cultivation of Tetracarpidium Conophorum. Encouragement of the cultivation of perilla, niger seed, chia oil, ongokea or isano oil, poy-ok oil and tee-seed oil is not recommended for reasons given.

The three main kinds of starch produced in the Colonies are arrowroot, sago flour and tapioca starch. There is every reason to increase the growing of arrowroot, and it is hoped that two grinding mills of an improved type will permit an increased yield to be obtained in St. Vincent from the root. Growing in Grenada is also proposed; but no unqualified recommendation is given for increased production of cassava for starch.

The Committee considered in detail the production and marketing prospects of a considerable number of essential oils ; it recommends, however, stimulation or exploration of production only for cajuput, cananga and ylang ylang, eucalyptus, geranium, juniper, lavender, neroli, patchouli, peppermint, petitgrain, spearmint, thyme, vetiver or 'cus-cus' and wormseed. Of the citrus oils, the production of a better quality of grapefruit oil should be encouraged. New production of citronella oil would have to compete in wellestablished markets, and future production of cloves and clove-stem oil in Zanzibar and Pemba is likely to be affected by a serious outbreak of the 'sudden death' disease.

With regard to timber, the Committee considers that while it will be a long time before softwood production can be developed on a large scale, the hardwood exports of British Colonial territories are capable of very substantial expansion; but maximum production cannot be secured without a great improvement in the supply of machinery, in communications and increased staff. There is much scope for research in sylviculture and conservation, and especially on utilization. Maximum production depends on such matters as the increased conversion of timber from the log, particularly of secondary timbers, to economize on the freight of logs by transporting them in semiprocessed form, and the development of veneer and plywood manufacture in the Colonies.

In regard to paper pulp, there are many products from which paper pulp of varying qualities can be made, but the number of economic materials is reduced by considerations of homogeneity, accessibility and certainty of supply. While there are a number of lines of inquiry, particularly into eucalyptus and wattle, which can be profitably pursued, the Committee believes there is at the moment no project which can be confidently recommended as a practical proposition. Reviewing the position of tanning materials, the Committee considers that owing to the war-time consumption of quebracho for fuel and the serious spread of disease among the chestnuts of South America, there is risk of a world shortage of vegetable tanning materials in the next twenty years if alternative sources of supply are not developed. Wattle is the most promising source of such materials in Colonial territories, and its cultivation should be encouraged, particularly on the highlands of East and Central Africa. The Committee also estimates that present schemes of development could increase Colonial production of tobacco by about fifty per cent, if the equipment, skilled labour, finance and fertilizers are forthcoming. While, however, the Colonies will continue to supply an appreciable part of the United Kingdom's requirements of pipe tobacco, they contribute to a very limited extent only to those of cigarette tobacco.

The Committee has also considered Dr. C. F. Hickling's report on "The Production of Fish in the Colonial Empire", since issued as Colonial No. 237*; it regards this report of the Fisheries Adviser to the Secretary of State for the Colonies as expressing adequately its own views. Dr. Hickling outlines the training now being given to some twenty-one fishery officers, and emphasizes the importance of studying methods of fish preservation with a view to their improvement by research. A fish preservation research officer is to be attached to headquarters, who will advise Colonial Governments as well as conduct research. A large sample of salted fish and of shark has been sent to the managers of the East African groundnut scheme for evaluation; and biological research on the fish taken in the survey of the Mauritius and Seychelles area of the Indian Ocean is also being carried out, and a biochemist has joined the survey. A West African Fisheries Research Institute is being established at Kessy Dockyard in Sierra Leone, and the scheme provides for long-term research on the productivity of the sea off West Africa. In Uganda, research is provided by the Fisheries Research Station at Jinja, and plans are being drawn up for a fisheries research station in Northern Rhodesia. Research in the South-East Asia region is to be provided for by a large research station, preferably at Singapore, which with its research vessel should cover the area from the Andaman Islands to North Borneo. A scheme has been approved for a centre for research and training in fish culture in Penang, Malaya.

Generally, it is considered that while there is considerable scope for increasing the Colonial production of fish, such increased production will be absorbed by the Colonies themselves, and except from the Gulf of Aden, Hong Kong and the Mauritius-Seychelles areas, surplus for export is unlikely. Increased production depends largely on the application of mechanized methods, which is hindered by difficulties in obtaining ships, equipment and trained staff. Although these deficiencies are being overcome, Colonial Governments must be prepared to make the necessary expenditure. Reference is also made to the development of by-products such as shark-liver oils, isinglass, and alginic acid and agar-agar from seaweeds.

* Colonial Office. Production of Fish in the Colonial Empire. (Colonial No. 237.) Pp. 14. (London : H.M. Stationery Office, 1949.) 4d. net. 